Review

\title{
Estrogen receptor transcription and transactivation Estrogen receptor alpha and estrogen receptor beta: regulation by selective estrogen receptor modulators and importance in breast cancer \\ Benita S Katzenellenbogen and John A Katzenellenbogen \\ University of Illinois and College of Medicine, Urbana, Illinois, USA
}

Received: 29 February 2000

Accepted: 26 May 2000

Published: 7 July 2000
Breast Cancer Res 2000, 2:335-344

(c) Current Science Ltd (Print ISSN 1465-5411; Online ISSN 1465-542X)

\begin{abstract}
Estrogens display intriguing tissue-selective action that is of great biomedical importance in the development of optimal therapeutics for the prevention and treatment of breast cancer, for menopausal hormone replacement, and for fertility regulation. Certain compounds that act through the estrogen receptor (ER), now referred to as selective estrogen receptor modulators (SERMs), can demonstrate remarkable differences in activity in the various estrogen target tissues, functioning as agonists in some tissues but as antagonists in others. Recent advances elucidating the tripartite nature of the biochemical and molecular actions of estrogens provide a good basis for understanding these tissue-selective actions. As discussed in this thematic review, the development of optimal SERMs should now be viewed in the context of two estrogen receptor subtypes, ER $\alpha$ and ER $\beta$, that have differing affinities and responsiveness to various SERMs, and differing tissue distribution and effectiveness at various gene regulatory sites. Cellular, biochemical, and structural approaches have also shown that the nature of the ligand affects the conformation assumed by the ER-ligand complex, thereby regulating its state of phosphorylation and the recruitment of different coregulator proteins. Growth factors and protein kinases that control the phosphorylation state of the complex also regulate the bioactivity of the ER. These interactions and changes determine the magnitude of the transcriptional response and the potency of different SERMs. As these critical components are becoming increasingly well defined, they provide a sound basis for the development of novel SERMs with optimal profiles of tissue selectivity as medical therapeutic agents.
\end{abstract}

Keywords: coactivators, corepressors, estrogen receptor, ligands for estrogen receptors, selective estrogen receptor modulators

\section{Introduction}

The pharmacology of various estrogens is intriguing. While many compounds are able to bind to the estrogen receptor (ER), they can differ markedly in their stimulatory and/or inhibitory effects. In addition, certain compounds, now referred to as selective estrogen receptor modulators (SERMs) $[1,2]$, can demonstrate remarkable differences in efficacy in the various tissues in which estrogens act,

$\mathrm{EGF}=$ epidermal growth factor; $\mathrm{ER}=$ estrogen receptor; $\mathrm{ERE}=$ estrogen response element; MAP $=$ mitogen-activated protein; NHE-RF $=$ sodium-hydrogen exchanger regulatory factor; SERM = selective estrogen receptor modulator; TGF $\beta 3=$ transforming growth factor $\beta 3$. 
functioning as agonists in some tissues but as antagonists in others. Such tissue-selective action is of great biomedical importance in the prevention and treatment of breast cancer, in menopausal hormone replacement, and in fertility regulation.

Originally termed an antiestrogen but now more properly designated as a SERM, tamoxifen is the most widely used agent in the treatment of breast cancer. In addition to its well documented effectiveness in the treatment of hormone-responsive breast cancer, there has been great excitement generated by the findings that tamoxifen [ $3^{\circ} \cdot$, as well as the related SERM raloxifene [4], are effective in preventing breast cancer in women at high risk for the disease. Despite these exciting new findings, it was also noted in the National Cancer Institute-sponsored Prevention Trial $\left[3^{\circ}\right]$ that tamoxifen was not a perfect SERM because there was increased incidence of endometrial cancer and venous thromboembolism. These findings highlight the importance of developing more optimal SERMs, particularly if these agents are to be used for breast cancer prevention and menopausal hormone replacement, where large numbers of healthy women would receive treatment for an extended period of time. An ideal SERM for these applications would be one that has no stimulatory action in the breast and uterus, and one that would block estrogen action at these sites, yet would act as an estrogen agonist in bone, liver, and the cardiovascular and central nervous systems.

\section{Tripartite receptor pharmacology: a framework for understanding the tissue-selective actions of estrogens}

Classical concepts in pharmacology cannot readily explain tissue selectivity in the actions of estrogens. However, recent advances in the molecular and cellular interactions of nuclear hormone receptors provide, for the first time, a view of many of the critical components that mediate the action of estrogens at the molecular level. These new findings provide a rich context within which one can begin to understand the unique properties of SERMs and to devise strategies for enhancing their desirable selective action.

As these findings were emerging a few years ago, we advanced the concept of 'tripartite receptor pharmacology' to provide a conceptual framework for understanding the tissue-selective actions of estrogens and other hormones for nuclear receptors (eg androgens, progestins, corticosteroids, etc), and the underlying molecular pharmacology [5]. The action of a particular estrogen, according to the tripartite receptor pharmacology scheme, is determined by three principal components: first, the structure of the ligand itself; second, the ER subtype or isoform with which the ligand binds to form a ligand-receptor complex of a particular conformation; and, finally, the interaction of this complex with an array of effector compo-
Figure 1

\section{ESTROGEN RECEPTOR TRIPARTITE PHARMACOLOGY}

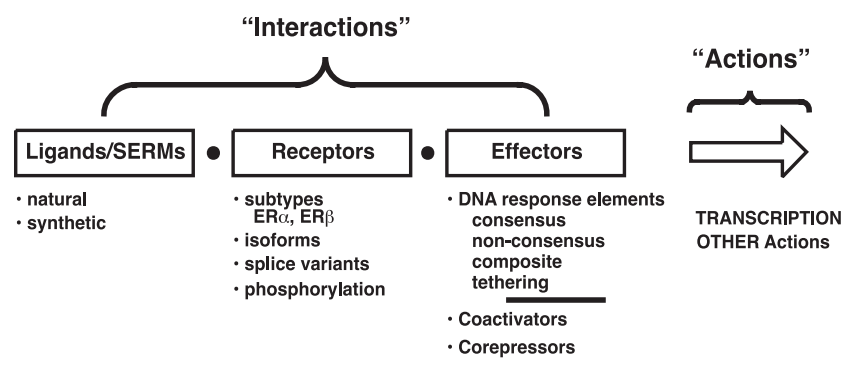

Estrogen receptor tripartite pharmacology. The diagram outlines the three components (ligands, receptors, and effectors) that together determine the magnitude and character of transcriptional and other responses to estrogens in target tissues.

nents through which the action of the hormone-receptor complex is linked to transcriptional regulation. The most critical effector components include the gene-regulatory DNA site to which the receptor binds (either directly or indirectly), as well as an array of coregulator proteins that determine the magnitude of the transcriptional response and its sensitivity to hormonal regulation (see Fig. 1). The hormone-receptor complex then recruits these coregulators, thereby linking the complex physically and/or functionally to the basal transcription complex and affecting the local chromatin structure.

\section{Estrogen receptor alpha and estrogen receptor beta: receptor subtypes that underlie the diversity of responses to estrogens and provide opportunities for the development of novel SERMs}

In thinking about the actions of SERMs, the discovery of a second ER gene, estrogen receptor-beta (ERB), now distinguished from the classical ER (denoted ER $\alpha$ ), is of particular importance $\left[6^{* *}, 7^{\circ}\right]$. ER $\alpha$ and ER $\beta$ differ significantly in their tissue distribution and ligand binding characteristics, as shown in this thematic review [8], thereby affording interesting potential for tissue-selective estrogen action.

While ER $\alpha$ and ER $\beta$ have nearly identical DNA-binding domains, these receptor subtypes have only $56 \%$ amino acid identity in their hormone binding domains, and they differ even more markedly (only $21 \%$ amino acid identity) in their $\mathrm{N}$-terminal activation function 1 regions. These differences suggest that it should be possible to identify ligands that will have different levels of potency or efficacy through the two ER subtypes, which would allow selective stimulation of diverse estrogen-regulated genes. Indeed, initial screening of known ER ligands showed that certain 

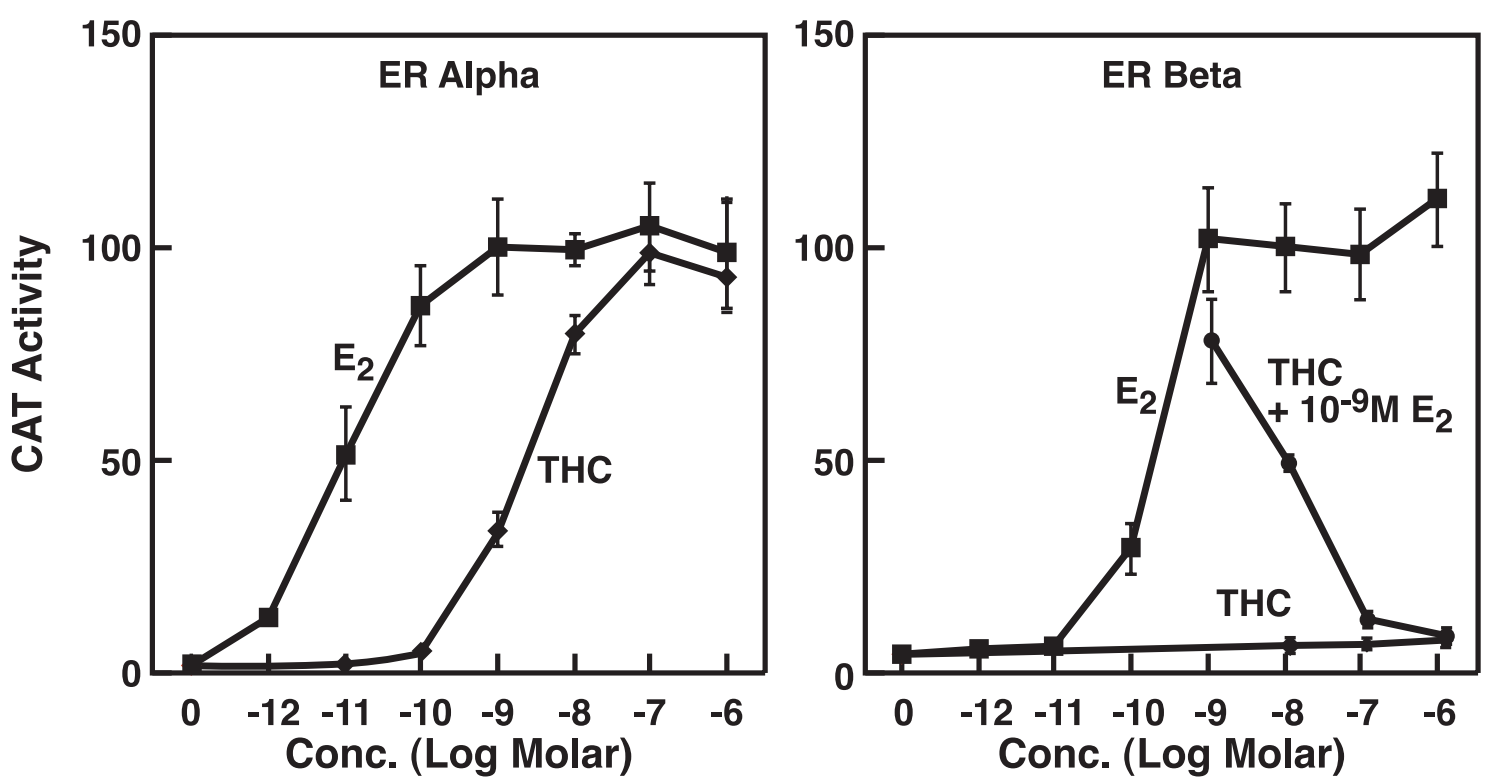

Transcription activation assays demonstrating that a tetrahydrochrysene (THC) ligand is an agonist on ER $\alpha$ and an antagonist on ER $\beta$. Transfection assays were conducted in human endometrial cancer cells using an estrogen-responsive reporter gene and either ER $\alpha$ or ER $\left[14^{* *}\right.$.

steroidal compounds exhibited moderate affinity and potency preference for $\mathrm{ER} \alpha$, whereas certain phytoestrogens and androgen-derived diols had moderate preference for ER $\beta$ [9 $^{\circ}$. In vivo studies have indeed shown that, compared with estradiol, the soy phytoestrogen genestein is more effective in providing vascular protection, presumably mediated through ER $\beta$, than uterine stimulation, presumably mediated through ER $\alpha\left[^{\circ}\right]$. SERMs such as hydroxytamoxifen and raloxifene that are partial agonists on ER $\alpha\left[11^{\circ}\right]$ were found to be complete antagonists on ER $\beta[12,13]$. Studies utilizing chimeric ER subtypes, in which the activation function 1 regions were exchanged, indicate that the agonism of these SERMs tracks with the activation function 1 of $\mathrm{ER} \alpha$ [12].

We have shown that it is possible to develop compounds of novel structure that can show remarkably high potency and/or efficacy selectivity on ER $\alpha$ and ER $\beta$. For example, we found that a triaryl pyrazole, which had nearly a 500fold binding affinity preference for $\mathrm{ER} \alpha$, could fully activate genes through $\mathrm{ER} \alpha$ at $1 \mathrm{nM}$, whereas there was no gene activation through ER $\beta$, even at $1 \mu \mathrm{M}\left[14^{\bullet \bullet}, 15\right]$. We have also developed a series of substituted tetrahydrochrysenes that were full agonists on $\mathrm{ER} \alpha$ but were complete antagonists on $\operatorname{ER} \beta$ (see Fig. 2) $\left[14^{\bullet \bullet}, 16^{\bullet}\right]$. Examinations with these compounds demonstrated that minor changes in the size and stereochemistry of the ligand substituents dramatically affected their activity as ER $\beta$ agonists or antagonists [16 ${ }^{\circ}$. These compounds are used to help define the respective biological roles of ER $\alpha$ and ER $\beta$ in the actions of estrogens in different target tissues. They are also being used to study, by X-ray crystallography, the ligand-induced conformation of the ER subtypes that mediate agonist versus antagonist activity. Genistein, which is more potent in activation of $\operatorname{ER} \beta$ than $\operatorname{ER} \alpha$, curiously induces a conformation of helix-12 in ER $\beta$ that is considered to resemble an antagonist complex more than

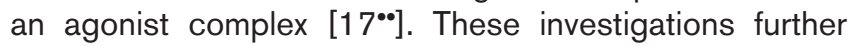
substantiate the observation that all agonists (or antagonists) do not contact the identical set of amino acids within the binding pocket of the receptor, nor induce identical receptor conformations $\left[18,19^{\circ}\right]$. This is consistent with prior observations of differences in ligand-receptor proteolysis profiles $\left[20^{\circ}, 21,22\right]$, as well as more recent studies using phage display of peptide probes, through which differences in the conformation of ER $\alpha$ and ER $\beta$ complexes with agonists and antagonists can be distinguished $\left[23^{\bullet}, 24^{\bullet}, 25\right]$.

There have been several active programs directed at the development of new SERMs, and a number of analogs of tamoxifen, raloxifene and other nonsteroidal ER ligands $[2,26,27]$ that appear to have favorable tissue-selective character have been described in the recent literature. The extent to which these new-generation SERMs act through $E R \alpha$ and ER $\beta$, and the degree to which they provide substantial improvements over estrogens and antiestrogens currently in use in hormone replacement and in breast cancer prevention and treatment, will require careful evaluation. Likewise, studies on steroidal estrogens used in 
hormone replacement have shown that some B-ring unsaturated compounds have distinct tissue-selective actions, being more efficacious in vasomotor, neuroendocrine and bone preservation parameters than in other peripheral actions of estrogens [28*]. The underlying bases for the tissue selectivity of these agents may be multifactorial, as discussed in this thematic review.

\section{Effector components I: the nature of the gene DNA response element through which the estrogen receptor regulates transcription}

Although the DNA binding domains of ER $\alpha$ and $E R \beta$ are nearly identical, there is considerable documentation that these receptor subtypes differ markedly in their abilities to activate different estrogen-responsive genes. This clearly highlights the fact that multiple regions of the receptor protein determine the specificity of gene activation [11 $\left.{ }^{\circ}\right]$. The fact that there are distinctly different modes of ER interaction with gene regulatory sites is of note in this regard. These different modes include direct binding of the receptor to estrogen response elements (EREs). These elements may be consensus or, more commonly, nonconsensus and may exist as single or multiple full or half sites; they may also be composite sites, consisting of EREs flanked by response elements for other transcription factors (such as Sp1), which themselves may or may not be occupied by their respective transactivating factors. It is interesting to note that there are differences in the affinities with which ER $\alpha$ and ER $\beta$ bind to the various EREs present in several estrogen-responsive genes (c-fos, c-jun, pS2, cathepsin D, choline acetyltransferase), measured by electrophoretic mobility gel shift assays, despite the near identity of the DNA-binding domains of the two receptors [29]. Studies showing that the DNA gene site itself also has an allosteric effect on the conformation of the ER monitored by protease digestion and immunoreactivity are relevant to this fact $[30,31]$.

In an alternate manner, ER may interact with DNA indirectly through tethering to other DNA-bound transcription factors, as appears to be the case with the interaction of the ERs at AP1 sites, where the receptor is tethered through the Fos/Jun complex $\left[32^{\circ *}, 33\right]$. Interestingly, the ERs also activate the quinone reductase gene $\left[34^{\circ *}, 35\right]$ and the transforming growth factor $\beta 3$ (TGF $\beta 3$ ) gene [36.] through regulatory regions at which they work along with other protein factors.

There are intriguing differences in the pharmacological character of estrogens acting through ER $\alpha$ versus ER $\beta$ at these various gene sites. Compounds that are normally agonists or antagonists at ERE sites showed similar agonist or antagonist behavior through $\mathrm{ER} \alpha$ at AP1 sites. When acting through ER $\beta$ at AP1 sites, however, compounds such as estradiol and diethylstilbestrol were curiously antagonistic, whereas antiestrogens such as hydroxytamoxifen and raloxifene showed strong stimulatory activity [32*0. Antiestrogens also activate the gene for quinone reductase, an antioxidant, detoxifying enzyme, with this stimulation being reversed by estrogens. This behavior is observed through both ER $\alpha$ and ER $\beta$, but the magnitude of stimulation appears to be somewhat greater through $\operatorname{ER} \beta\left[34^{* *}, 35\right]$. The upregulation of the quinone reductase gene by antiestrogens may contribute to the beneficial effects of antiestrogens in breast cancer prevention as well as treatment. The TGF $\beta 3$ gene in bone cells is also better stimulated by antiestrogen ligands, such as raloxifene, and by some equilin-type estrogens than by estradiol, although the respective roles of ER $\alpha$ and ER $\beta$ in this response have not been elucidated [36 $6^{\circ}$.

These and other studies highlight not only the importance of the nature of the gene promoter site itself, but also the cell background (ie whether uterine, breast cancer, bone, or another type of cell) in determining the pharmacology of the hormone-receptor complex. This is due, at least in part, to differences in activity of the receptor activation functions in different cell backgrounds, reflecting differences in the balance and spectrum of coregulator proteins present in different types of cells $\left[3^{\circ *}, 38,39^{\circ}, 40\right]$. It is also relevant to note that there is interaction between the two major ( $\mathrm{N}$ - and $\mathrm{C}$-terminal) activation function-containing regions of the ER, allowing for the synergistic regulation of transcription of many genes $\left[41^{\circ}, 42\right]$.

\section{Effector components II: coregulator proteins}

The ER works with many other proteins in the regulation of gene expression. These coregulators play several critical roles: they affect the magnitude of gene stimulation or repression ([43-47] and references cited therein); they influence ligand dissociation kinetics [48]; and they alter the dose-response profile to hormone $[48,49]$. The magnitude of stimulation or repression of receptor transcriptional activity can be considered as first determined by the nature of the ligand, which controls the recruitment of coregulators to the ligand-receptor complex $\left[50^{\bullet *}, 51^{\circ *}\right]$. The agonist-receptor complex, most notably, recruits the p160 family of coactivators and other proteins, some of which possess histone acetyltransferase activity. Of interest in this regard in breast cancer is the report that AIB1/SRC-3/ACTR is amplified and upregulated in a significant number of breast tumors [52]. Such a change might indicate that these tumors show enhanced sensitivity to estrogens that may have affected tumorigenesis and/or progression of the disease.

The antagonist-receptor complex recruits other coregulators, including an ER-selective repressor of estrogen receptor activity (denoted REA) that enhances the inhibitory potency of antiestrogens [ $\left.51^{\circ}{ }^{\circ}\right]$, as well as N-CoR and SMRT $\left[53,54^{\circ} \cdot\right.$. The balance between coactivators and corepressors in breast cancers is considered to be an 
important determinant of the agonist/antagonist activity of SERMs. There is already evidence that the level of N-CoR is correlated with tamoxifen sensitivity or resistance [54 ${ }^{\circ \bullet}$ ], and L7/SPA is recruited by the ER $\alpha$-tamoxifen complex and acts specifically to enhance the agonism by antiestrogen, an effect that is reversed by $\mathrm{N}-\mathrm{CoR}\left[55^{\circ}\right]$. There is clear evidence for transcription factor specific requirements for coregulators [56], and mounting evidence for differential recruitment of coregulators by the occupied ER $\alpha$-receptor and ER $\beta$-receptor complexes, with the nature of the ligand and the nature of the receptor subtype determining the preference for different coregulators [57].

Since ER $\alpha$ and ER $\beta$ can also form heterodimers when both are present in the same cell [58,59], these heterodimers could potentially also differ from either homodimer complex in the profile of coregulators that are recruited to a hormone-receptor complex. This may be of importance in some breast cancers. Both ER $\alpha$ and $E R \beta$ are present in most breast cancers, although $\mathrm{ER} \alpha$ is usually the predominant form $\left[60,61,62^{\circ}\right]$. There is also evidence for several splice variants and other isoforms of both ER $\alpha$ and ER $\beta$ that might also differ in their bioactivity from the wild-type receptor forms $[60,63]$. Since there is evidence that ER $\beta$ can modulate the activity of $\mathrm{ER} \alpha$ under some circumstances [64], it is possible that normal breast development as well as breast cancer progression may be accompanied by changes in the ratios of these two receptors [8]. Whether the onset of tamoxifen resistance might be explained by changes in either the levels or bioactivity of these two receptors or changes in its coregulator partners (such as SRCs or REA) is equally important. In the case of $E R \alpha$, there is evidence for changes in cell signaling pathways that impact on the ER in tamoxifen-resistant breast cancer [65], as well as evidence for the presence of mutations in $\mathrm{ER} \alpha$ in a small proportion of tamoxifenresistant breast cancers [66-68]. The role of ER $\beta$ (wild type and variant) in breast cancer and in tamoxifen resistance needs to be investigated further.

The development of tamoxifen resistance limits the effective treatment of hormone-responsive breast cancer with this drug. This has placed a premium on understanding the mechanism by which tamoxifen resistance develops [69-71]. Although many hypotheses have been advanced, it now appears likely that the resistance to antiestrogen therapy most frequently results from a cellular adaptation process. One such process may involve a change in the cellular milieu of coactivators and corepressors (as well as changes in cell signaling pathways; see later) such that they abrogate the tumor growth inhibitory activity of the ER-tamoxifen complex, and/or may even make this complex a growth stimulator (see, for example, $\left[54^{\bullet \bullet}, 65\right]$ ).

Very relevant in this regard are the recent studies using phage-displayed peptides in which certain peptides that specifically recognized ER complexes with the active tamoxifen metabolite, hydroxytamoxifen, were found to block selectively the partial agonistic activity of this ligand, without affecting the agonism of estradiol [24 ${ }^{\circ}$. This suggests that specific coregulator proteins, distinct from those involved in mediating the agonism of estrogens such as estradiol, are responsible for mediating the agonistic actions of antiestrogens such as tamoxifen. Learning how such factors are regulated in the cell, particularly with prolonged tamoxifen exposure, may lead to a greater understanding of the mechanism of tamoxifen resistance and may open up new approaches for preventing the development of this therapy-limiting cellular adaptation.

\section{Crosstalk between the estrogen receptor and other cell signaling pathways}

A considerable number of studies have documented the fact that growth factors (eg epidermal growth factor [EGF], insulin-like growth factor), cAMP and other agents (eg dopamine) can stimulate activity of the ER and also alter the agonist/antagonist balance of SERMs $\left[72,73,7^{\circ}\right.$, $\left.75,76^{\circ}, 77\right]$. There is mounting evidence for changes in growth factor and protein kinase pathways in hormone resistance in breast cancer ([69] and references cited therein). Stimulation of the protein kinase A signaling pathway, in particular, enhanced the agonistic activity of tamoxifen-like antiestrogens, and reduced the antagonistic effectiveness of this and related SERMs; observations that may in part account for the development of tamoxifen resistance by some ER-containing breast cancers [73]. Tamoxifen-resistant breast cancer cells also showed complete insensitivity to growth inhibition by TGF $\beta$ and reduced sensitivity to the growth inhibitory effects of retinoic acid, supporting interrelationships among the cell regulatory pathways utilized by these three growth-suppressive agents [65]. The effects of many of these agents are believed to reflect their ability to change the phosphorylation state of ER, as well as that of coregulators and other proteins with which the ER interacts to modulate gene expression. Interestingly, there is considerable evidence for interactions between cAMP and estrogen in regulating growth of the mammary gland and breast cancer cells $[78,79]$.

Several groups have documented enhanced phosphorylation of ER on serine residues upon hormone occupancy as well as upon cell exposure to cAMP and some growth factors. Insulin-like growth factor and EGF stimulation, as well as estrogen stimulation, of ER transcriptional activity are associated with phosphorylation of several serine residues present in the $\mathrm{N}$-terminal activation function 1 region of $E R \alpha$ and $E R \beta\left[76^{\circ}, 80-84\right]$. These include, most notably, Ser-118 in ER $\alpha$ (and the equivalent serine in $\mathrm{ER} \beta$ ), a mitogen-activated protein (MAP) kinase site, and Ser 167 in ER $\alpha$, which appears to be a pp90rsk1 site [85]. While growth factor-induced phosphorylation of Ser-118 
by MAP kinase is well documented, there is evidence that another kinase may be involved in estrogen-induced phosphorylation of Ser-118. The cAMP-stimulated phosphorylation of ER probably occurs on different residues of the ER [82]. Mutational analyses indicate that these sites play an important role in the transactivation ability of the ER $\left[76^{\circ}, 82,83,85,86\right]$.

Crosstalk between the ER and EGF signaling systems has been nicely documented more recently in the ER $\alpha$ knockout mouse, where the mice lose responsiveness to the EGF, as well as to estrogen, in the uterus [87]. Our observations that the sodium-hydrogen exchanger regulatory factor (NHE-RF, also known as EBP50) is upregulated by estrogen suggests that this protein may serve as a link between the ER and some cell signaling pathways [88]. NHE-RF has been shown to interact with ezrin-radixinmoesin cytoskeletal proteins that link actin filaments to the cell membrane, an interaction that may mediate the estrogen-induced changes in cellular architecture ([88] and references cited therein). NHE-RF also interacts through its two PDZ domains with several important receptors, including the beta-adrenergic receptor, the plateletderived growth factor receptor, and the cystic fibrosis transporter receptor, and may thereby provide a link between ER and these other regulatory pathways.

The issue of whether hormone-dependent phosphorylation of the ER involves tyrosine residues and whether this affects receptor activity has been controversial. Several articles have reported phosphorylation of ER $\alpha$ on tyrosine 537 and provided evidence for the role of this site in regulating hormone binding and DNA binding of the receptor $[89,90]$. However, other studies involving replacement of this residue with amino acids incapable of being phosphorylated, indicate that phosphorylation at this site is not required for hormone or DNA binding, nor for transcriptional activity of the receptor [21,91-94]. The amino acid substitution studies revealed that substitution of certain amino acids for tyrosine 537 in ER $\alpha$ (and at the corresponding tyrosine in ER $\beta$ [95]) produced constitutively active ERs (ie ERs fully active in the absence of hormone). These findings suggest that the nature of the residue at this position, which is at the start of helix-12, may facilitate the shift of this helix into an active conformation and/or allow stabilization of the receptor in its active form [21,91-93].

Aside from the well documented synergistic effects of estrogens and some protein kinase activators and growth factors on gene transcription (see, for example, [96 ${ }^{\circ}$ ), estrogens also exert rapid membrane-initiated effects that are known to impact importantly on cell signaling and may also influence nuclear gene transcription. For example, estrogens increase the overall levels of tyrosine phosphorylation in cells [97], increase intracellular calcium concentration in some cells $[98,99]$, increase the phosphorylation of CREB [100], activate G protein-coupled signaling [101], and rapidly increase MAP kinase activity associated with estrogen stimulation of cell proliferation [99,102*0]. Several studies suggest that these effects may be due to ERs present in the membrane that are similar to those that mediate gene transcription in the nucleus $\left[101,103,104^{\circ}\right]$, although other studies indicate a receptor pharmacology and ligand selectivity different from that of the classical nuclear ERs [98,105]. This remains an area of great importance and active investigation.

\section{Conclusion}

There have been great advances in our understanding of the biochemical and molecular basis for biomedically important tissue selective actions of estrogens. The development of optimal SERMs for the prevention and treatment of breast cancer, and for hormone replacement therapy and fertility regulation, can now be viewed in the context of two estrogen receptor subtypes, ER $\alpha$ and ER $\beta$, that have differing affinities and responsiveness to various SERMs, and differing tissue distribution and effectiveness at different gene regulatory sites. Cellular, biochemical, and structural approaches have revealed that the nature of the ligand affects the conformation assumed by the ER-ligand complex, thereby regulating its state of phosphorylation and the recruitment of different coactivators and corepressors that determine the magnitude of the transcriptional response and its sensitivity to the SERM. The ER and its ligands do not work in isolation in various estrogen target tissues; the ER also has its bioactivity regulated by growth factors and various protein kinases that regulate its phosphorylation, as well as the state of phosphorylation of coregulator proteins with which it interacts. As these critical components are becoming increasingly well defined, they provide a sound basis for the development of novel SERMs with optimal profiles of tissue selectivity as medical therapeutic agents.

\section{Acknowledgements}

We are grateful to the scientists in our laboratories for their important contributions. We regret that many important references could not be cited, due to space limitations.

\section{References}

Articles of particular interest have been highlighted as:

- of special interest

- of outstanding interest

1. McDonnell DP: The molecular pharmacology of SERMs. Trends Endocrinol Metab 1999, 10:301-311.

2. Grese TA, Dodge JA: Selective estrogen receptor modulators (SERMS). Curr Pharmacol Design 1998, 4:71-92.

3. Fisher B, Costantino JP, Wickerham DL, Redmond CK, Kavanah M, - Cronin WM, Vogel V, Robidoux A, Dimitrov N, Atkins J, Daly M, Wieand S, Tan-Chiu E, Ford L, Wolmark N: Tamoxifen for prevention of breast cancer: report of the National Surgical Adjuvant Breast and Bowel Project P-1 Study. J Natl Cancer Inst 1998, 90:13711388.

This is an important summary of the findings of the large tamoxifen breast cancer prevention clinical trial. 
4. Cummings SR, Eckert S, Krueger KA, Grady D, Powles TJ, Cauley JA, Norton L, Nickelsen T, Bjarnason NH, Morrow M, Lippman ME, Black $D$, Glusman JE, Costa A, Jordan VC: The effect of raloxifene on risk of breast cancer in postmenopausal women: results from the MORE randomized trial. Multiple Outcomes of Raloxifene Evaluation. JAMA 1999, 281:2189-2197.

5. Katzenellenbogen JA, O'Malley BW, Katzenellenbogen BS: Tripartite steroid hormone receptor pharmacology: interaction with multiple effector sites as a basis for the cell- and promoter-specific action of these hormones. Mol Endocrinol 1996, 10:119-131.

6. Kuiper GJM, Enmark E, Pelto-Huikko M, Nilsson S, Gustafsson JA:

- Cloning of a novel estrogen receptor expressed in rat prostate and ovary. Proc Natl Acad Sci USA 1996, 93:5925-5930.

This is the first publication on the cloning of estrogen receptor beta in the rat and indication of its high expression in ovary and prostate.

7. Mosselman S, Polman J, Dijkema R: ERß: identification and charac-

- terization of a novel human estrogen receptor. FEBS Lett 1996, 392:49-53.

The first publication on the cloning of human estrogen receptor beta from the testis.

8. Nilsson S, Gustafsson J-A: Estrogen receptor transcription and transactivation: basic aspects of estrogen action. Breast Cancer Res 2000, 2:360-366.

9. Kuiper GGJM, Carlsson B, Grandien J, Enmark E, Haggblad J, Nilsson

- S, Gustafsson JA: Comparison of the ligand binding specificity and transcript tissue distribution of estrogen receptors $\alpha$ and $\beta$. Endocrinology 1997, 138:863-870.

An important study demonstrating the differences in affinity of some ligands for estrogen receptors alpha and beta, and the overlapping, but also distinct, tissue distribution of these receptor subtypes.

10. Makela S, Savolainen H, Aavik E, Myllarniemi M, Strauss L, Taskinen E,

- Gustafsson JA, Hayry P: Differentiation between vasculoprotective and uterotrophic effects of ligands with different binding affinities to estrogen receptors alpha and beta. Proc Natl Acad Sci USA 1999, 96:7077-7082.

A comparison of genistein versus estradiol, demonstrating target tissue selectivity of genistein in its vasculoprotective activity with minimal uterine stimulatory activity.

11. Mclnerney EM, Katzenellenbogen BS: Different regions in activation

- function-1 of the human estrogen receptor required for antiestrogen- and estradiol-dependent transcription activation. J Biol Chem 1996, 271:24172-24178.

An analysis of ER $\alpha$ demonstrating that different regions of activation function 1 support the agonistic activity of tamoxifen and estradiol.

12. Mclnerney EM, Weis KE, Sun J, Mosselman S, Katzenellenbogen BS: Transcription activation by the human estrogen receptor subtype $\beta(E R \beta)$ studied with ER $\beta$ and $E R \alpha$ receptor chimeras. Endocrinology 1998, 139:4513-4522.

13. Tremblay GB, Tremblay A, Copeland NG, Gilbert DJ, Jenkins NA, Labrie F, Giguere V: Cloning, chromosomal localization, and functional analysis of the murine estrogen receptor $\beta$. Mol Endocrinol 1997, 11:353-365.

14. Sun J, Meyers MJ, Fink BE, Rajendran R, Katzenellenbogen JA,

- Katzenellenbogen BS: Novel ligands that function as selective estrogens or anti-estrogens for estrogen receptor- $\alpha$ or estrogen receptor- $\beta$. Endocrinology 1999, 140:800-804.

This is the first report on ligands that are highly selective for one of the two estrogen receptor subtypes, and the identification of a selective ER $\beta$ antagonist ligand.

15. Stauffer SR, Sun J, Katzenellenbogen BS, Katzenellenbogen JA: Acyclic amides as estrogen receptor ligands. Bioorg Med Chem 2000 , in press.

16. Meyers MJ, Sun J, Carlson KE, Katzenellenbogen BS, Katzenellen-

- bogen JA: Estrogen receptor subtype-selective ligands: asymmetric synthesis and biological evaluation of cis- and trans-5,11-dialkyl5,6,11,12-tetrahydrochrysenes. J Med Chem 1999, 42:2456-2468.
A study of structure-activity relationships in a novel nonsteroidal ligand system, demonstrating that substituent size and stereochemistry regulate $\mathrm{ER} \beta$ antagonist activity.

17. Pike AC, Brzozowski AM, Hubbard RE, Bonn T, Thorsell AG,

-• Engstrom O, Ljunggren J, Gustafsson J, Carlquist M: Structure of the ligand-binding domain of oestrogen receptor beta in the presence of a partial agonist and a full antagonist. EMBO J 1999, 18:46084618.

The first X-ray crystal structure of the hormone binding domain of ER $\beta$.

18. Ekena KE, Weis KE, Katzenellenbogen JA, Katzenellenbogen BS: Identification of amino acids in the hormone binding domain of the human estrogen receptor important in estrogen binding. J Biol Chem 1996, 271:20053-20059.

19. Ekena K, Weis KE, Katzenellenbogen JA, Katzenellenbogen BS: Dif- ferent residues of the human estrogen receptor are involved in the recognition of structurally diverse estrogens and antiestrogens. J Biol Chem 1997, 272:5069-5075.

A study using alanine scanning mutagenesis demonstrating that different estrogens have a different pattern of contact residues in helix-11 of ER $\alpha$. This report also defined the orientation of estrogens in the ligand binding pocket, with the steroid D-ring contacting helix-11.

20. McDonnell DP, Clemm DL, Hermann T, Goldman ME, Pike JW: Analy- $\quad$ sis of estrogen receptor function in vitro reveals three distinct classes of antiestrogens. Mol Endocrinol 1995, 9:659-669.

A study showing a spectrum in degree of estrogen antagonism of different antiestrogens that reflected conformational changes in the ER $\alpha$-antiestrogen complex.

21. Lazennec G, Ediger TR, Petz LN, Nardulli AM, Katzenellenbogen BS: Mechanistic aspects of estrogen receptor activation probed with constitutively active estrogen receptors: correlations with DNA and coregulator interactions and receptor conformational changes. Mol Endocrinol 1997, 11:1375-1386.

22. Allan GF, Leng X, Tsai SY, Weigel NL, Edwards DP, Tsai MJ, O'Malley GW: Hormone and antihormone induce distinct conformational changes which are central to steroid receptor activation. $J$ Biol Chem 1992, 267:19513-19520.

23. Paige LA, Christensen DJ, Gron H, Norris JD, Gottlin EB, Padilla KM, -• Chang C, Ballas LM, Hamilton PT, McDonnell DP, Fowlkes DM: Estrogen receptor (ER) modulators each induce distinct conformational changes in ER alpha and ER beta. Proc Natl Acad Sci USA 1999, 96:3999-4004.

A novel study that used a peptide phage display library approach to identify differences in the conformation of ER $\alpha$ and ER $\beta$ when complexed with different agonist and antagonist ligands.

24. Norris JD, Paige LA, Christensen DJ, Chang CY, Huacani MR, Fan D, - Hamilton PT, Fowlkes DM, McDonnell DP: Peptide antagonists of the human estrogen receptor. Science 1999, 285:744-746.

An interesting application of conformation-selective peptides to block the agonistic activity of tamoxifen, without affecting the agonistic activity of estradiol.

25. Chang C, Norris JD, Gron H, Paige LA, Hamilton PT, Kenan DJ, Fowlkes D, McDonnell DP: Dissection of the LXXLL nuclear receptor-coactivator interaction motif using combinatorial peptide libraries: discovery of peptide antagonists of estrogen receptors alpha and beta. Mol Cell Biol 1999, 19:8226-8239.

26. Rosati RL, Jardine PD, Cameron KO, Thompson DD, Ke HZ, Toler SM, Brown TA, Pan LC, Ebbinghaus CF, Reinhold AR, Elliott NC, Newhouse BN, Tjoa CM, Sweetnam PM, Cole MJ, Arriola MW, Gauthier JW, Crawford DT, Nickerson DF, Pirie CM, Qi H, Simmons HA, Tkalcevic GT: Discovery and preclinical pharmacology of a novel, potent, nonsteroidal estrogen receptor agonist/antagonist, $\mathrm{Cp}-336156$, a diaryltetrahydronaphthalene. J Med Chem 1998, 41:2928-2931.

27. Willson TM, Norris JD, Wagner BL, Asplin I, Baer P, Brown HR, Jones SA, Henke B, Sauls H, Wolfe S, Morris DC, McDonnell DP: Dissection of the molecular mechanism of action of GW5638, a novel estrogen receptor ligand, provides insights into the role of estrogen receptor in bone. Endocrinology 1997, 138:3901-3911. 
28. Baracat E, Haidar M, Lopez FJ, Pickar J, Dey M, Negro-Vilar A: Estro- gen activity and novel tissue selectivity of $\Delta^{8,9}$ dehydroestrone sulfate in postmenopausal women. J Clin Endocrinol Metab 1999, 84:2020-2027.

An interesting study in women demonstrating that B-ring modified estrogens have distinct tissue-selective actions.

29. Hyder SM, Chiappetta C, Stancel GM: Interaction of human estrogen receptors alpha and beta with the same naturally occurring estrogen response elements. Biochem Pharmacol 1999, 57:597-601.

30. Lefstin JA, Yamamoto KR: Allosteric effects of DNA on transcriptional regulators. Nature 1998, 392:885-888.

31. Wood JR, Greene GL, Nardulli AM: Estrogen response elements function as allosteric modulators of estrogen receptor conformation. Mol Cell Biol 1998, 18:1927-1934.

32. Paech K, Webb P, Kuiper GGJM, Nilsson S, Gustafsson J-A, Kushner - PJ, Scanlan TS: Differential ligand activation of estrogen receptors ER $\alpha$ and ER $\beta$ at AP1 sites. Science 1997, 277:1508-1510.

A study demonstrating that estrogens and antiestrogens show different levels of agonist versus antagonist activity at different gene sites, through $E R \alpha$ and $E R \beta$.

33. Webb P, Nguyen P, Valentine C, Lopez GN, Kwok GR, Mclnerney E, Katzenellenbogen BS, Enmark E, Gustafsson JA, Nilsson S, Kushner PJ: The estrogen receptor enhances AP-1 activity by two distinct mechanisms with different requirements for receptor transactivation functions. Mol Endocrinol 1999, 13:1672-1685.

34. Montano MM, Katzenellenbogen BS: The quinone reductase gene: a -. unique estrogen receptor-regulated gene that is activated by antiestrogens. Proc Natl Acad Sci USA 1997, 94:2581-2586.

A study documenting that quinone reductase, an antioxidant, chemoprotective gene, is regulated by estrogens and antiestrogens with 'reversed pharmacology', being upregulated by antiestrogens, with this action blocked by estrogens. Antiestrogen regulation was shown to require functional ER and to be mediated via the electrophile response element region of the quinone reductase gene.

35. Montano MM, Jaiswal AK, Katzenellenbogen BS: Transcriptional regulation of the human quinone reductase gene by antiestrogen-liganded estrogen receptor- $\alpha$ and estrogen receptor- $\beta$. J Biol Chem $1998,273: 25443-25449$.

36. Yang NN, Venugopalan M, Hardikar S, Glasebrook A: Identification - $\quad$ of an estrogen response element activated by metabolites of 17$\beta$-estradiol and raloxifene. Science 1996, 273:1222-1225.

An early demonstration that $E R \alpha$ can activate genes when tethered to a response element through other proteins. In this system, certain antiestrogens and estradiol metabolites were especially potent, more so than estradiol.

37. Tora L, White J, Brou C, Tassett D, Webster N, Scheer E, Chambon P: -. The human estrogen receptor has two independent transcriptional nonacidic activation functions. Cell 1989, 59:477-487.

The first demonstration that two separable activation functions are present in $\mathrm{ER} \alpha$ and mediate its transcriptional activity. This study laid the groundwork for many subsequent investigations.

38. Bocquel MT, Kumar V, Chambon P, Gronemeyer H: The contribution of the $\mathrm{N}$ - and $\mathrm{C}$-terminal regions of steroid receptors to activation of transcription is both receptor and cell specific. Nucl Acids Res 1989, 17:2581-2595.

39. Tzukerman MT, Esty A, Santiso-Mere D, Danielian P, Parker MG, Stein - $\quad$ RB, Pike JW, McDonnell DP: Human estrogen receptor transactivational capacity is determined by both cellular and promoter context and mediated by two functionally distinct intramolecular regions. Mol Endocrinol 1994, 8:21-30.

A comprehensive study demonstrating that the transcriptional activity of the two activation functions in ER $\alpha$ depends on the cell and promoter context.

40. Shim W-S, DiRenzo J, DeCaprio JA, Santen RJ, Brown M, Jeng M-H: Segregation of steroid receptor coactivator-1 from steroid receptors in mammary epithelium. Proc Natl Acad Sci USA 1999, 96:208-213.
41. Kraus WL, Mclnerney EM, Katzenellenbogen BS: Ligand-dependent, - transcriptionally productive association of the amino- and carboxyl-terminal regions of a steroid hormone nuclear receptor. Proc Natl Acad Sci USA 1995, 92:12314-12318.

A study demonstrating that agonist, but not antagonist ligands promote a transcriptionally functional association between the $\mathrm{N}$ - and C-terminal portions of ER $\alpha$.

42. Mclnerney EM, Tsai MJ, O'Malley BW, Katzenellenbogen BS: Analysis of estrogen receptor transcriptional enhancement by a nuclear hormone receptor coactivator. Proc Natl Acad Sci USA 1996, 93: 10069-10073.

43. Shibata H, Spencer TE, Onate SA, Jenster G, Tsai SY, Tsai M-J, O'Malley BW: Role of co-activators and co-repressors in the mechanism of steroid/thyroid receptor action. Recent Prog Horm Res 1997, 52:141-165.

44. Horwitz KB, Jackson TA, Bain DL, Richer JK, Takimoto GS: Nuclear receptor coactivators and corepressors. Mol Endocrinol 1996, 10: $1167-1177$

45. Glass CK, Rose DW, Rosenfeld MG: Nuclear receptor coactivators. Curr Opin Cell Biol 1997, 9:222-232.

46. McKenna NJ, Lanz RB, O'Malley BW: Nuclear receptor coregulators: cellular and molecular biology. Endocr Rev 1999, 20:321-344.

47. Glass CK, Rosenfeld MG: The coregulator exchange in transcriptional functions of nuclear receptors. Genes Dev 2000, 14:121-141.

48. Gee AC, Carlson KE, Martini PG, Katzenellenbogen BS, Katzenellenbogen JA: Coactivator peptides have a differential stabilizing effect on the binding of estrogens and antiestrogens with the estrogen receptor. Mol Endocrinol 1999, 13:1912-1923.

49. Szapary D, Huang Y, Simons SS Jr: Opposing effects of corepressor and coactivators in determining the dose-response curve of agonists, and residual agonist activity of antagonists, for glucocorticoid receptor-regulated gene expression. Mol Endocrinol 1999, 13:2108-2121.

50. Onate SA, Tsai SY, Tsai MJ, O'Malley BW: Sequence and character-. ization of a coactivator for the steroid hormone receptor super family. Science 1995, 270:1354-1357.

The first identification of a nuclear receptor coactivator (SRC-1), using a yeast two-hybrid screen with the hormone binding domain of the progesterone receptor.

51. Montano MM, Ekena K, Delage-Mourroux R, Chang W, Martini P, - Katzenellenbogen BS: An estrogen receptor-selective coregulator that potentiates the effectiveness of antiestrogens and represses the activity of estrogens. Proc Natl Acad Sci USA 1999, 96:6947-6952.

Characterization of a coregulator that selectively interacts with $\mathrm{ER} \alpha$ and ER $\beta$ but not other nuclear receptors. This protein enhances the potency of antiestrogens and represses estradiol activation of the ER.

52. Anzick SL, Kononen J, Walker RL, Azorsa DO, Tanner MM, Guan X-Y Sauter G, Kallioniemi O-P, Trent JM, Meltzer PS: AIB1, a steroid receptor coactivator amplified in breast and ovarian cancer. Science 1997, 277:965-968.

53. Smith CL, Nawaz Z, O'Malley BW: Coactivator and corepressor regulation of the agonist/antagonist activity of the mixed antiestrogen, 4-hydroxytamoxifen. Mol Endocrinol 1997, 11:657-666.

54. Lavinsky RM, Jepsen K, Heinzel T, Torchia J, Mullen T-M, Schiff R, Del-

-• Rio AL, Ricote M, Ngo S, Gemsch J, Hilsenbeck SG, Osborne CK, Glass CK, Rosenfeld MG, Rose DW: Diverse signaling pathways modulate nuclear receptor recruitment of N-CoR and SMRT complexes. Proc Natl Acad Sci USA 1998, 95:2920-2925.

A study demonstrating that corepressors modulate the antagonist activity of tamoxifen, and that corepressor expression is reduced in tamoxifen-resistant breast tumors. 
55. Jackson TA, Richer J, Bain DL, Takimoto GS, Tung L, Horwitz KB: The - partial agonist activity of antagonist-occupied steroid receptors is controlled by a novel hinge domain-binding coactivator L7/SPA and the corepressors N-CoR or SMRT. Mol Endocrinol 1997, 11:693-705.

This paper is a good demonstration that the balance between coactivators and corepressors regulates the level of agonist activity of certain antihormone-receptor complexes.

56. Korzus E, Torchia J, Rose DW, Xu L, Kurokawa R, Mclnerney EM, Mullen T-M, Glass CK, Rosenfeld MG: Transcription factor-specific requirements for coactivators and their acetyltransferase functions. Science 1998, 279:703-707.

57. Kraichely DM, Sun J, Katzenellenbogen JA, Katzenellenbogen BS: Conformational changes and coactivator recruitment by novel ligands for estrogen receptor alpha and estrogen receptor beta: Correlations with biological character and distinct differences among SRC coactivator family members. Endocrinology 2000, 141 in press.

58. Cowley SM, Hoare S, Mosselman S, Parker MG: Estrogen receptors $\alpha$ and $\beta$ form heterodimers on DNA. J Biol Chem 1997, 272: 19858-19862.

59. Pace $\mathrm{P}$, Taylor J, Suntharalingam $\mathrm{S}$, Coombes RC, Ali S: Human estrogen receptor beta binds DNA in a similar to and dimerizes with estrogen receptor alpha. J Biol Chem 1997, 272:25832-25838.

60. Vladusic EA, Hornby AE, Guerra-Vladusic FK, Lupu R: Expression of estrogen receptor $\beta$ messenger RNA variant in breast cancer. Cancer Res 1998, 58:210-214.

61. Dotzlaw $\mathrm{H}$, Leygue $\mathrm{E}$, Watson PH, Murphy LC: Expression of estrogen receptor- $\beta$ in human breast tumors. J Clin Endocrinol Metab 1997, 82:2371-2377.

62. Leygue E, Dotzlaw H, Watson PH, Murphy LC: Altered estrogen

- receptor $\alpha$ and $\beta$ messenger RNA expression during human breast tumorigenesis. Cancer Res 1998, 58:3197-3201.

A study suggesting that changes in the expression of ER $\alpha$ and ER $\beta$ may be important factors accompanying the process of breast tumorigenesis.

63. Zhang Q-X, Hilsenbeck SG, Fuqua SAW, Borg A: Multiple splicing variants of the estrogen receptor are present in individual human breast tumors. J Steroid Biochem Mol Biol 1996, 59:251-260.

64. Hall JM, McDonnell DP: The estrogen receptor beta-isoform (ERß) of the human estrogen receptor modulates ER alpha transcriptional activity and is a key regulator of the cellular response to estrogens and antiestrogens. Endocrinology 1999, 140:5566-5578.

65. Herman ME, Katzenellenbogen BS: Response-specific antiestrogen resistance in a newly characterized MCF-7 human breast cancer cell line resulting from long-term exposure to trans-hydroxytamoxifen. J Steroid Biochem Mol Biol 1996, 59:121-134.

66. Karnik PS, Kulkarni S, Liu X, Budd GT, Bukowski RM: Estrogen receptor mutation in tamoxifen-resistant breast cancer. Cancer Res 1994, 54:349-353.

67. Wolf DM, Jordan VC: Characterization of tamoxifen stimulated MCF-7 tumor variants grown in athymic mice. Breast Cancer Res Treat 1994, 31:117-127.

68. Levenson AS, Jordan VC: The key to the antiestrogenic mechanism of raloxifene is amino acid 351 (aspartate) in the estrogen receptor. Cancer Res 1998, 58:1872-1875.

69. Katzenellenbogen BS, Montano MM, Ekena K, Herman ME, Mclnerney EM: Antiestrogens: mechanisms of action and resistance in breast cancer. Breast Cancer Res Treat 1997, 44:23-38.

70. Morrow M, Jordan VC: Molecular mechanisms of resistance to tamoxifen therapy in breast cancer. Arch Surg 1993, 128:1187-1191.

71. Osborne CK, Fuqua SAW: Mechanisms of tamoxifen resistance. Breast Cancer Res Treat 1994, 32:49-55.
72. Aronica SM, Katzenellenbogen BS: Stimulation of estrogen receptor-mediated transcription and alteration in the phosphorylation state of the rat uterine estrogen receptor by estrogen, cyclic adenosine monophosphate, and insulin-like growth factor-I. Mol Endocrinol 1993, 7:743-752.

73. Fujimoto N, Katzenellenbogen BS: Alteration in the agonist/antagonist balance of antiestrogens by activation of protein kinase A signaling pathways in breast cancer cells: antiestrogen-selectivity and promoter-dependence. Mol Endocrinol 1994, 8:296-304.

74. Ignar-Trowbridge DM, Nelson KG, Bidwell MC, Curtis SW, Washburn

- TF, McLachlan JA, Korach KS: Coupling of dual signaling pathways: epidermal growth factor action involves the estrogen receptor. Proc Natl Acad Sci USA 1992, 89:4658-4662.

An early documentation of the interrelationships between the ER and the growth factor signal transduction pathways.

75. Bunone G, Briand PA, Miksicek RJ, Picard D: Activation of the unliganded estrogen receptor by EGF involves the MAP kinase pathway and direct phosphorylation. EMBO J 1996, 15:2174-2183.

76. Kato $\mathrm{SH}$, Endoh $\mathrm{Y}$, Masuhiro $\mathrm{Y}$, Kitamoto $\mathrm{T}$, Uchiyama S, Sasaki $\mathrm{H}$

- Masucshige S, Gotoh Y, Nishida E, Kawashima H, Metzger D, Chambon P: Activation of the estrogen receptor through phosphorylation by mitogen-activated protein kinase. Science 1995, 270:1491-1494.

An important demonstration that the N-terminal (AF-1) region of ER is a target for phosphorylation through the MAP kinase pathway, and that phosphorylation at this site enhances ER transactivation.

77. Weigel NL: Steroid hormone receptors and their regulation by phosphorylation. Biochem J 1996, 319:657-667.

78. Sheffield LG, Welsch CW: Cholera-toxin-enhanced growth of human breast cancer cell lines in vitro and in vivo: interaction with estrogen. Int J Cancer 1985, 36:479-483.

79. Silberstein GB, Strickland PS, Trumpbour V, Coleman S, Daniel CW: cAMP stimulates growth and morphogenesis of mouse mammary ducts. Proc Natl Acad Sci USA 1984, 81:4950-4954.

80. Tremblay A, Tremblay GB, Labrie F, Giguere V: Ligand-independent recruitment of SRC-1 to estrogen receptor beta through phosphorylation of activation function AF-1. Mol Cell 1999, 3:513-519.

81. Arnold SF, Obourn JD, Jaffe H, Notides AC: Serine 167 is the major estradiol-induced phosphorylation site on the human estrogen receptor. Mol Endocrinol 1994, 8:1208-1214.

82. LeGoff $\mathrm{P}$, Montano MM, Schodin DJ, Katzenellenbogen BS: Phosphorylation of the human estrogen receptor: identification of hormone-regulated sites and examination of their influence on transcriptional activity. J Biol Chem 1994, 269:4458-4466.

83. Ali S, Metzger D, Bornert J-M, Chambon P: Phosphorylation of the human oestrogen receptor: identification of a phosphorylation site required for transactivation. EMBO J 1993, 12:1153-1160.

84. Lahooti H, White R, Hoare SA, Rahman D, Pappin DJC, Parker MG: Identification of phosphorylation sites in the mouse oestrogen receptor. J Steroid Biochem Mol Biol 1995, 55:305-313.

85. Joel PB, Smith J, Sturgill TW, Fisher TL, Blenis J, Lannigan DA: pp90rsk1 regulates estrogen receptor-mediated transcription through phosphorylation of Ser-167. Mol Cell Biol 1998, 18:19781984.

86. Joel PB, Traish AM, Lannigan DA: Estradiol-induced phosphorylation of serine 118 in the estrogen receptor is independent of p42/p44 mitogen-activated protein kinase. J Biol Chem 1998, 273:13317-13323.

87. Couse JF, Korach KS: Estrogen receptor null mice: what have we learned and where will they lead us? Endocr Rev 1999, 20:358417. 
88. Ediger TR, Kraus WL, Weinman EJ, Katzenellenbogen BS: Estrogen receptor regulation of the $\mathrm{Na}^{+} / \mathrm{H}^{+}$exchanger regulatory factor. Endocrinology 1999, 140:2976-2982.

89. Castoria G, Migliaccio A, Green S, Di Domenico M, Chambon P, Auricchio F: Properties of a purified estradiol-dependent calf uterus tyrosine kinase. Biochemistry 1993, 32:1740-1750.

90. Arnold SF, Vorojeikina DP, Notides AC: Phosphorylation of tyrosine 537 on the human estrogen receptor is required for binding to an estrogen response element. J Biol Chem 1995, 270:30205-30212.

91. Weis KE, Ekena K, Thomas JA, Lazennec G, Katzenellenbogen BS: Constitutively active human estrogen receptors containing amino acid substitutions for tyrosine 537 in the receptor protein. $\mathrm{Mol}$ Endocrinol 1996, 10:1388-1398.

92. White R, Sjoberg M, Kalkhoven E, Parker MG: Ligand-independent activation of the oestrogen receptor by mutation of a conserved tyrosine. EMBO J 1997, 16:1427-1435.

93. Zhang Q-X, Borg A, Wolf DM, Oesterreich S, Fuqua SAW: An estrogen receptor mutant with strong hormone-independent activity from a metastatic breast cancer. Cancer Res 1997, 57:1244-1249.

94. Yudt MR, Vorojeikina D, Zhong L, Skafar DF, Sasson S, Gasiewicz TA, Notides AC: The function of estrogen receptor tyrosine 537 in hormone binding, DNA binding and transactivation. Biochemistry 1999, 38:14146-14156.

95. Tremblay GB, Tremblay A, Labrie F, Giguere V: Ligand-independent activation of the estrogen receptors $\alpha$ and $\beta$ by mutations of a conserved tyrosine can be abolished by antiestrogens. Cancer Res 1998, 58:877-881.

96. Cho $\mathrm{H}$, Katzenellenbogen BS: Synergistic activation of estrogen - receptor-mediated transcription by estradiol and protein kinase activators. Mol Endocrinol 1993, 7:441-452.

An early demonstration of cross-talk between ER and phosphorylation pathways, also indicating cell- and promoter-specific effects of protein kinase activators on ER-mediated transcription.

97. Auricchio F, Migliaccio A, Castoria G, Di Domenico M, Bilancio A, Rotondi A: Protein tyrosine phosphorylation and estradiol action. Ann N Y Acad Sci 1996, 784:149-172.

98. Lieberherr M, Grosse B, Kachkache M, Balsan S: Cell signaling and estrogens in female rat osteoblasts: a possible involvement of unconventional nonnuclear receptors. J Bone Miner Res 1993, 8: $1365-1376$

99. Improta-Brears T, Whorton AR, Codazzi F, York JD, Meyer T, McDonnell DP: Estrogen-induced activation of mitogen-activated protein kinase requires mobilization of intracellular calcium. Proc Natl Acad Sci USA 1999, 96:4686-4691.

100. Zhou Y, Watters JJ, Dorsa DM: Estrogen rapidly induces the phosphorylation of the cAMP response element binding protein in rat brain. Endocrinology 1996, 137:2163-2166.

101. Razandi M, Pedram A, Greene GL, Levin ER: Cell membrane and nuclear estrogen receptors (ERs) originate from a single transcript: studies of ER $\alpha$ and ER $\beta$ expressed in chinese hamster ovary cells. Mol Endocrinol 1999, 13:307-319.

102. Migliaccio A, Di Domenico M, Castoria G, de Flaco A, Bontempo P, - Nola E, Auricchio F: Tyrosine kinase/p21ras/MAP-kinase pathway activation by estradiol-receptor complex in MCF-7 cells. EMBO J 1996, 15:1292-1300.

A critical demonstration of the involvement of the MAP kinase pathway and tyrosine kinases in the signaling and proliferative activities of estrogen.

103. Watson CS, Norfleet AM, Pappas TC, Gametchu B: Rapid actions of estrogens in GH3/B6 pituitary tumor cells via a plasma membrane version of estrogen receptor-alpha. Steroids 1999, 64:5-13.
104. Pappas TC, Gametchu B, Watson CS: Membrane estrogen recep- $\quad$ tors identified by multiple antibody labeling and impeded-ligand binding. FASEB J 1995, 9:404-410.

Several antibodies to different portions of ER $\alpha$ are shown to detect ER in the membrane, indicating that intracellular ER and membrane-associated ER are related.

105. Zheng J, Ramirez VD: Demonstration of membrane estrogen binding proteins in rat brain by ligand blotting using a $17 \beta$-estradiol-[125I] bovine serum albumin conjugate. J Steroid Biochem Mol Biol 1997, 62:327-336.

Authors' affiliations: Benita S. Katzenellenbogen (Departments of Molecular and Integrative Physiology, and Cell and Structural Biology, University of Illinois and College of Medicine, Urbana, Illinois, USA) and John A. Katzenellenbogen (Department of Chemistry, University of Illinois, Urbana, Illinois, USA)

Sponsorship: The research described in this review was supported by grants from the National Institutes of Health, the US Army, and The Breast Cancer Research Foundation

Correspondence: Dr Benita S Katzenellenbogen, Department of Molecular and Integrative Physiology, University of Illinois at UrbanaChampaign, 524 Burrill Hall, 407 South Goodwin Avenue, Urbana, IL 61801-3704, USA. Tel: +1 217333 9769/7838;

fax: +1 217244 9906; e-mail: katzenel@uiuc.edu 